\title{
KANDUNGAN FITOKIMIA dan UJI AKTIFITAS ANTIOKSIDAN EKSTRAK METANOL KULIT RAMBUTAN (Nephelium lappaceum L) VARIETAS BINJAI DAN LEBAK BULUS
}

Zulhipri, Yusnetty Boer, dan Rosallia Pramu Dyaningtyas

Jurusan Kimia Fakultas MIPA Universitas Negeri Jakarta Jl. Pemuda No 10, Rawamangun 13220, Jakarta, Indonesia

Corresponding author: zulhipri@yahoo.co.id

\begin{abstract}
Abstrak
Telah dilakukan uji fitokimia dan aktivitas antioksidan terhadap kulit rambutan (Nephelium lappaceum L) yang merupakan tanaman buah khas Indonesia. Penelitian ini bertujuan untuk menentukan kemampuan antioksidan dari kulit rambutan varietas Binjai dan Lebak bulus yang dinyatakan dengan nilai $I_{50}$. Pembuatan ekstrak dilakukan dengan cara maserasi menggunakan pelarut metanol. Uji aktivitas antioksidan menggunakan metode Penangkapan Radikal DPPH (2,2-difenil-1-pikrilhidrazil.) Hasil pengujian fitokimia menunjukkan bahwa ekstrak kulit rambutan varietas Binjai dan Lebak bulus mengandung senyawa metabolit sekunder golongan fenolik, flavonoid, steroid, terpenoid dengan kandungan dominan golongan fenolik. Hasil pengujian antioksidan diperoleh nilai $\mathrm{IC}_{50}$ ekstrak metanol kulit rambutan varietas Binjai dan Lebak bulus berturut-turut adalah 31,722 dan 27,636 ppm yang sebanding dengan Asam askorbat dengan ${ } \mathrm{C}_{50}$ sebesar $30,848 \mathrm{ppm}$.
\end{abstract}

Keywords : rambutan, fenolik, antioksidan, DPPH

\begin{abstract}
It has been tested phytochemical and antioxidant activity of the skin of rambutan (Nephelium lappaceum L) which is a typical Indonesian fruit crops. This study aimed to determine the antioxidant capacity of the skin of rambutan varieties Binjai and Lebak bulus represented by IC 50 values. Preparation of extracts made by maceration using methanol solvent. Antioxidant activity assay using DPPH Radical Fishing (2,2-diphenyl-1pikrilhidrazil.) Phytochemical Test results showed that the varieties of rambutan peel extract Binjai and Lebak bulus containing secondary metabolites classes of phenolic, flavonoids, steroids, terpenoids with a dominant content of phenolic groups. The results of antioxidant testing IC 50 values obtained methanol extract rambutan skin varieties Binjai and Lebak Bulus respectively 31.722 and 27.636 ppm is comparable to ascorbic acid with IC ${ }_{50}$ of 30.848 ppm.
\end{abstract}

Keywords : rambutan, phenolic, antioxidants, DPPH

\section{Pendahuluan}

Rambutan (Nephelium lappaceum. L) merupakan salah satu tanaman buah yang banyak terdapat di Indonesia. Ada beberapa jenis rambutan yang dikenal diantaranya adalah rambutan Aceh, Binjai, Garuda, Lebak bulus, Rapiah, Simacan, Sinyonya, dan lain-lain [1]. Dari buah rambutan biasanya yang dikonsumsi adalah daging buahnya, sedangkan kulit dan bijinya dibuang begitu saja dan belum dimanfaatkan dengan baik. Di sisi lain secara tradisional tanaman rambutan digunakan untuk pengobatan berbagai penyakit. Kulit buah rambutan berkhasiat untuk pengobatan disentri dan demam, kulit kayu untuk obat sariawan, daun untuk obat diare dan menghitamkan rambut, akar untuk obat demam serta bijinya untuk mengatasi diabetes mellitus [2].

Kulit buah rambutan telah dilaporkan mengandung senyawa-senyawa golongan tanin, polifenol dan saponin. Biji rambutan mengandung lemak dan polifenol. Daun mengandung tanin dan saponin. Kulit batang mengandung tanin, polifenol dan flavonoid [3]. Beberapa penenlitian terbaru mengungkapkan bahwa kulit buah dan bijibijian, seperi biji dan kulit anggur, kulit buah delima, kulit jeruk manis berpotensi memiliki 
Tabel 1. Hasil uji fitokimia ekstrak metanol kulit rambutan binjai dan lebak bulus

\begin{tabular}{|c|c|c|}
\hline \multirow{2}{*}{$\begin{array}{c}\text { Uji } \\
\text { Golongan }\end{array}$} & \multicolumn{2}{|c|}{ Jenis Rambutan } \\
\cline { 2 - 3 } Steroid & Binjai & Lebak Bulus \\
\hline Triterpenoid & + & + \\
\hline Alkaloid & - & + \\
\hline Fenolik & +++ & - \\
\hline Saponin & + & +++ \\
\hline Flavonoid & + & + \\
\hline
\end{tabular}

Keterangan:

- $\quad$ = tidak ada zat aktif dalam sampel

$+\quad=$ kandungan zat aktif relatif rendah

$++\quad=$ kandungan zat aktif relatif sedang

$+++=$ kandungan zat aktif relatif tinggi

aktivitas antioksidan [4]. Melihat kulit buah rambutan yang mengandung tanin dan polifenol, dapat diduga kulit rambutan berpotensi memiliki aktivitas antioksidan. Hal ini didukung oleh hasil penelitian yang dilakukan oleh Thitilertdecha dkk tahun 2007, yang melaporkan sifat antioksidan dan antibakteri dari kulit dan biji rambutan jenis yang tumbuh di Thailand [5]. Kemudian pada tahun 2010, Thitilertdecha dkk juga telah berhasil mengisolasi 3 senyawa golongan fenolik dari ekstrak metanol kulit rambutan yang teridentifikasi sebagai Ellagic Acid (EA), corilagin dan geraniin [6].

Penelitian ilmiah mengenai aktivitas antioksidan dari kulit buah rambutan yang tumbuh di Indonesia hingga saat ini belum pernah dilakukan. Oleh karena itu, pada penelitian ini dilakukan uji aktivitas antioksidan kulit rambutan dengan menguji ativitas antioksidan terhadap ekstrak pelarut polar metanol. Ekstrak pelarut polar ini diduga mengandung senyawa-senyawa golongan fenolik yang nantinya diharapkan memiliki aktivitas antioksidan. Jenis rambutan yang dipilih pada penelitian ini adalah jenis Binjai dan Lebak bulus (Nephelium lappaceu L) yang merupakan jenis rambutan yang banyak dikonsumsi masyarakat. Pada penelitian ini ekstrak methanol yang diperoleh dilakukan uji identifikasi kandungan fitokimianya. Selanjutnya ekstrak methanol ini dilakukan uji antioksidan dengan metoda penangkapan radikal DPPH

\section{Metodologi Penelitian}

Penelitian dilakukan di laboratorium Kimia FMIPA UNJ. Sampel kulit rambutan dikumpulkan dari kebun buah Taman Wisata Mekarsari Cilengsi Bogor. Metode penelitian yang digunakan adalah : ekstraksi cara maserasi dengan pelarut metanol, uji fitokimia dengan pereaksi pengenal golongan senyawa metabolit sekunder golongan alkaloid, fenolik, flavonoid, steroid dan terpenoi. Penelitian ini dilakukan dengan tahapan, yaitu: (1) Persiapan sampel kulit rambutan varietas Binjai dan Lebak bulus dari pengumpulan kulit rambutan sampai diperoleh serbuk kering halus, (2) Pembuatan ekstrak pelarut dengan metode maserasi menggunakan pelarut metanol, (3) Uji fitokimia senyawa metabolit sekunder golongan alkaloid, fenolik, flavonoid, steroid dan terpenoid terhadap ekstrak [7], (4) Uji aktifitas antioksidan dengan metode penangkapan radikal DPPH (1,1-difenil-2pikrilhidrazil) dengan pengulangan pekerjaan sebanyak tiga kali [8].

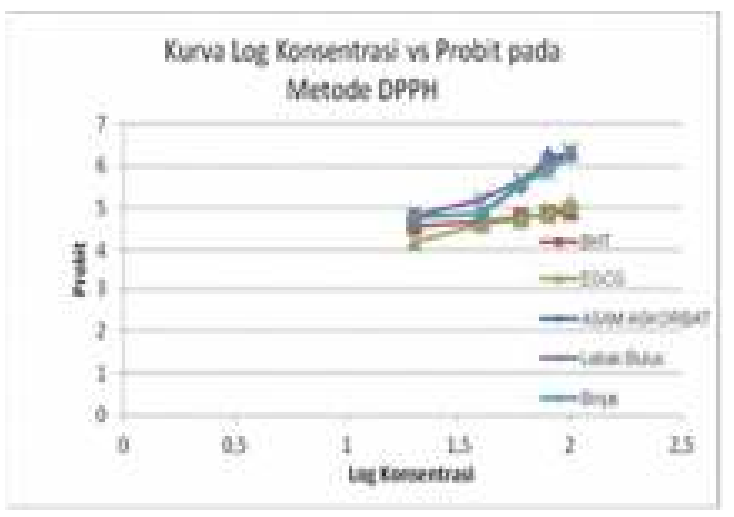

Gambar 1. Kurva log konsentrasi Vs probit pada metode DPPH 


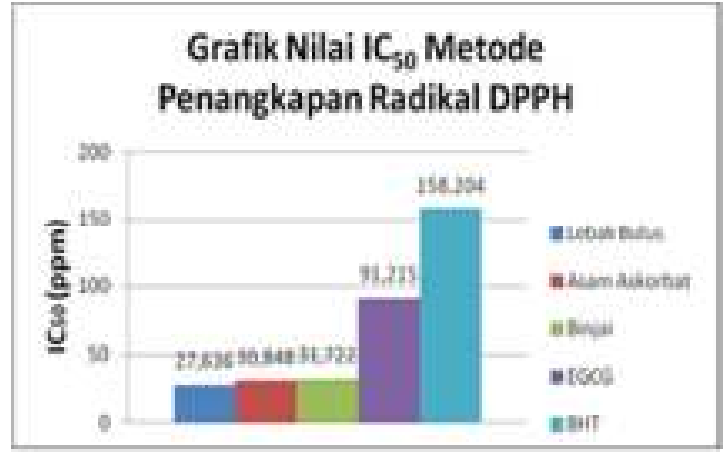

Gambar 2. Nilai IC50 ekstrak methanol kulit rambutan binjai, lebak bulus serta pembanding asam askorbat, BHT dan EGCG pada metode DPPH

Kimia FMIPA UNJ. Sampel kulit rambutan dikumpulkan dari kebun buah Mekar Sari Cilengsi. Metode penelitian yang digunakan adalah : ekstraksi cara maserasi dengan pelarut metanol, uji fitokimia dengan pereaksi pengenal golongan senyawa metabolit sekunder golongan alkaloid, fenolik, flavonoid, steroid dan terpenoi. Penelitian ini dilakukan dengan tahapan, yaitu: (1) Persiapan sampel kulit rambutan varietas Binjai dan Lebak bulus dari pengumpulan kulit rambutan sampai diperoleh serbuk kering halus, (2) Pembuatan ekstrak pelarut dengan metode maserasi menggunakan pelarut metanol, (3) Uji fitokimia senyawa metabolit sekunder golongan alkaloid, fenolik, flavonoid, steroid dan terpenoid terhadap ekstrak [7], (4) Uji aktifitas antioksidan dengan metode penangkapan radikal DPPH (1,1-difenil-2pikrilhidrazil) dengan pengulangan pekerjaan sebanyak tiga kali [8].

\section{Hasil dan Pembahasan}

Ekstraksi dengan Pelarut Metanol

Ekstraksi senyawa yang terkandung dalam kulit rambutan (Nephelium lappaceum L.) varietas Binjai dan Lebak bulus dilakukan dengan menggunakan metode maserasi. Hasil maserasi terhadap 100 gram serbuk kering masing-masing varietas Binjai dan Lebak bulus berturut-turut diperoleh ekstrak kasar berwarna coklat dengan rendemen $38 \%$ dan
$41,6 \%$ dari berat serbuk kering mula-mula. Hasil ini menunjukan bahwa ekstraksi dengan pelarut metanol ini dapat menarik senyawa metabolit sekunder dalam kulit rambutan dengan baik. Hal ini dapat dikaitkan dengan kandungan senyawa fenolik yang bersifat polar yang merupakan kandungan dominan dalam kulit buah rambutan ini.

Uji fitokimia dilakukan untuk mengetahui senyawa metabolit sekunder yang terkandung dalam ekstrak methanol kulit rambutan varietas Binjai dan lebak Bulus. Pengujian dilakukan meliputi golongan senyawa alkaloid, fenolik, flavonoid, saponin, steroid, dan terpenoid. Hasil uji fitokimia dapat dilihat pada Tabel 1 berikut :

Dari tabel 1 di atas terlihat bahwa kulit buah kedua jenis rambutan yang diuji menunjukkan hasil pengujian sama, yaitu mengandung senyawa golongan fenolik, flavonoid, steroid dan terpenoid, sedangkan alkaloid tidak ada. Kandungan senyawa metabolit sekunder yang relatif tinggi yaitu senyawa fenolik yang ditandai dengan kadar relatif positif tiga $(+++)$. Hasil ini memberi petunjuk bahwa kulit buah kedua jenis rambutan ini memilki potensi memiliki aktivitas antiokasidan. Senyawa fenolik dicirikan oleh adanya cincin aromatik dengan satu atau lebih gugus hidroksil. Beberapa studi menyatakan senyawa fenolik memiliki aktivitas sebagai antioksidan, seperti senyawa Epigalokatekin galat (EGCG) pada teh hijau yang telah terbukti memiliki aktivitas antioksidan [4].

\section{Uji Aktifitas Antioksidan}

Pengukuran aktivitas antioksidan dengan metode DPPH dilakukan dengan cara mereaksikan sampel ekstrak metanol dengan larutan DPPH. Reaksi ditandai dengan perubahan warna dari ungu menjadi kuning, setelah dan sebelum inkubasi. Proses inkubasi pada penelitian ini dilakukan selama 30 menit. Tujuannya adalah untuk mengoptimalkan 
reaksi antara radikal DPPH dengan sampel yang bertindak sebagai anti oksidan yang di tandai dengan perubahan warna larutan.

Tabel 2. Data absorbansi ekstrak metanol kulit rambutan binjai, lebak bulus serta pembanding asam askorbat, BHT dan EGCG.

\begin{tabular}{|c|c|c|c|c|c|}
\hline \multirow[t]{2}{*}{ Larutan } & \multirow{2}{*}{$\begin{array}{c}\text { Konsentrasi } \\
(\mathrm{ppm})\end{array}$} & \multicolumn{3}{|c|}{ Absorbansi } & \multirow{2}{*}{$\bar{A}$} \\
\hline & & 1 & 2 & 3 & \\
\hline Kontrol & & & & & 0,4432 \\
\hline \multirow{5}{*}{$\mathrm{BHT}$} & 20 & 0,288 & 0,291 & 0,292 & 0,290 \\
\hline & 40 & 0,275 & 0,274 & 0,271 & 0,273 \\
\hline & 60 & 0,258 & 0,253 & 0,252 & 0,254 \\
\hline & 80 & 0,245 & 0,24 & 0,236 & 0,240 \\
\hline & 100 & 0,229 & 0,226 & 0,226 & 0,227 \\
\hline \multirow{5}{*}{ EGCG } & 20 & 0,335 & 0,332 & 0,355 & 0,340 \\
\hline & 40 & 0,281 & 0,262 & 0,303 & 0,282 \\
\hline & 60 & 0,25 & 0,18 & 0,364 & 0,266 \\
\hline & 80 & 0,234 & 0,221 & 0,241 & 0,232 \\
\hline & 100 & 0,199 & 0,189 & 0,204 & 0,197 \\
\hline \multirow{5}{*}{$\begin{array}{c}\text { ASAM } \\
\text { ASKORBAT }\end{array}$} & 20 & 0,255 & 0,253 & 0,249 & 0,252 \\
\hline & 40 & 0,22 & 0,244 & 0,243 & 0,236 \\
\hline & 60 & 0,136 & 0,128 & 0,127 & 0,130 \\
\hline & 80 & 0,047 & 0,044 & 0,044 & 0,045 \\
\hline & 100 & 0,041 & 0,042 & 0,04 & 0,041 \\
\hline \multirow{5}{*}{$\begin{array}{l}\text { LEBAK } \\
\text { BULUS }\end{array}$} & 20 & 0,25 & 0,252 & 0,246 & 0,249 \\
\hline & 40 & 0,171 & 0,18 & 0,192 & 0,181 \\
\hline & 60 & 0,108 & 0,109 & 0,106 & 0,108 \\
\hline & 80 & 0,069 & 0,066 & 0,064 & 0,066 \\
\hline & 100 & 0,038 & 0,039 & 0,039 & 0,039 \\
\hline \multirow{5}{*}{ BINJAI } & 20 & 0,267 & 0,256 & 0,256 & 0,260 \\
\hline & 40 & 0,234 & 0,233 & 0,234 & 0,234 \\
\hline & 60 & 0,118 & 0,116 & 0,119 & 0,118 \\
\hline & 80 & 0,082 & 0,088 & 0,089 & 0,086 \\
\hline & 100 & 0,047 & 0,042 & 0,045 & 0,045 \\
\hline
\end{tabular}

Larutan yang telah diinkubasi selanjutnya diukur aktivitas antioksidannya secara spektrofotometri. Pengukuran absorbansi sampel dilakukan pada berbagai konsentrasi yaitu 20, 40, 60, 80, dan 100 ppm pada panjang gelombang $517 \mathrm{~nm}$ yang dibandingkan dengan beberapa senyawa yang telah diketahui aktivitas antioksidannya, seperti Butilated hidroksi Toluen (BHT), EGCG, dan Asam askorbat. Data absorbansi sampel dan pembanding ditampilkan pada Tabel 2 berikut :

Dari hasil pengukuran absorbansi pada Tabel 2, terjadi penurunan nilai absorbansi seiring dengan meningkatnya konsentrasi baik pada masing-masing sampel maupun pada pembanding. Hal ini memperlihatkan penurunan daya serap akibat berkurangnya jumlah radikal DPPH yang berwarna ungu berubah menjadi anti radikal $\mathrm{DPPH}$. Penurunan absorban ini berhubungan banyaknya atom $\mathrm{H}$ yang didonorkan oleh antioksidan kepada radikal bebas. Semakin banyak atom $\mathrm{H}$ yang didonorkan maka perubahan warna ungu ke kuning menjadi semakin konsinten [9]. Pada Tabel 2 juga bahwa ekstrak metanol kulit rambutan varietas Binjai dan Lebak bulus mengalami perubahan warna yang signifikan yaitu dari ungu menjadi kuning muda. Perubahan tersebut mengindikasikan bahwa ekstrak metanol kulit rambutan ini mampu mendonorkan atom $\mathrm{H}$-nya yang ditandai dengan nilai absorbansi yang semakin menurun.

Aktivitas antioksidan dan $\mathrm{IC}_{50}$ merupakan parameter yang digunakan untuk mengukur kemampuan kerja antioksidan. Aktivitas antioksidan menunjukkan kemampuan suatu zat dalam menghambat radikal bebas yang dinyatakan dalam bentuk persen penghambatan, sedangkan $\mathrm{IC}_{50}$ menunjukkan konsentrasi suatu antioksidan dalam menghambat sebesar 50\% aktivitas dari radikal bebas. Nilai persen penghambatan sampel dan pembanding diperoleh dari pengolahan nilai absorbansi. Berikut disajikan nilai persen penghambatan pada Tabel 3 .

Dari Tabel 3 dapat diamati bahwa Asam askorbat memiliki persen penghambat radikal tertinggi ke-2 setelah ekstrak metanol kulit rambutan Lebak bulus. Nilai persen penghambatan antara sampel dengan asam askorbat yang tidak jauh berbeda menunjukkan bahwa kedua ekstrak metanol kulit rambutan tersebut memiliki kemampuan menghambat radikal bebas yang hampir sama dengan asam askorbat.

Parameter lain yang digunakan untuk mengetahui kemampuan antioksidan dalam 
Tabel 3. Data persentase antioksidan ekstrak metanol kulit rambutan binjai, lebak bulus serta pembanding asam askorbat, BHT dan EGCG dengan berbagai Konsentrasi

\begin{tabular}{|c|c|c|c|c|c|}
\hline \multirow{2}{*}{$\begin{array}{c}\text { Konsentras } \\
\text { i (ppm) }\end{array}$} & \multicolumn{5}{|c|}{$\%$ Penghambat } \\
\cline { 2 - 6 } & BHT & EGCG & $\begin{array}{c}\text { As. } \\
\text { Askorbat }\end{array}$ & $\begin{array}{c}\text { Lebak } \\
\text { Bulus }\end{array}$ & Binjai \\
\hline 20 & 32,793 & 21,142 & 41,589 & 42,284 & 39,892 \\
\hline 40 & 36,728 & 34,722 & 45,447 & 58,102 & 45,910 \\
\hline 60 & 41,126 & 38,734 & 69,830 & 75,077 & 72,7623 \\
\hline 80 & 44,367 & 46,296 & 89,583 & 84,645 & 80,015 \\
\hline 100 & 47,454 & 54,321 & 90,509 & 91,049 & 89,660 \\
\hline
\end{tabular}

suatu sampel adalah nilai $I_{50}$. Nilai $I_{50}$ (Inhibition Concentration) adalah konsentrasi senyawa antioksidan yang dibutuhkan untuk menghambat lima puluh persen aktivitas dari suatu senyawa radikal bebas. Nilai $I_{50}$ diperoleh dengan merubah nilai persen penghambatan menjadi probit dan konsentrasi menjadi log konsentrasi kemudian nilai probit dan log konsentrasi yang diperoleh dibuat menjadi kurva [10]. Adapun kurva log konsentrasi dengan probit ditampilkan pada Gambar 1.

Dari kurva hubungan antara log konsentrasi dengan probit pada Gambar 1 di atas, dapat dilihat bahwa kedua varietas kulit rambutan memiliki pola aktivitas antioksidan yang menyerupai aktivitas senyawa pembanding asam askorbat.

Dari kurva pada Gambar 1 juga dapat diperoleh persamaan garis dari masing-masing sampel dan pembanding dalam bentuk $y=m x$ + c yang digunakan untuk menentukan nilai $I_{50}$. Nilai $I C_{50}$ pada ekstrak metanol kulit rambutan varietas Binjai dan Lebak bulus serta beberapa pembanding disajikan dalam grafik pada Gambar 2 berikut :Dari grafik pada Gambar 2 di atas, dapat dilihat bahwa Ekstrak metanol kulit rambutan varietas Lebak bulus memiliki nilai $I_{50}$ terkecil yaitu sebesar 27,636 ppm selanjutnya berturut-turut Asam askorban, Kulit rambutan Binjai, EGCG, BHT sebesar 30,848 ppm ; 31,722 ppm ; 91,215 ppm ; 158,204 ppm. Semakin kecil nilai $I_{50}$ maka semakin efektif sampel tersebut sebagai antioksidan. Begitu sebaliknya, semakin besar nilai $I_{50}$ maka semakin tidak efektif sampel tersebut sebagai antioksidan.

Kedua sampel yaitu ekstrak metanol rambutan varietas Binjai dan Lebak bulus memiliki nilai persen penghambatan radikal dan $I_{50}$ yang tidak jauh berbada dengan Asam askorbat yang sudah teruji khasiatnya sebagai suatu antioksidan alami. Sehingga demikian dapat dinyatakan bahwa ekstrak metanol kulit rambutan varietas Binjai dan Lebak bulus memiliki potensi untuk dijadikan antioksidan alami yang baik.

\section{Kesimpulan}

a. Ekstrak metanol kulit rambutan Binjai dan Lebak bulus mengandung senyawa golongan fenolik, flavonoid, steroid dan terpenoid dengan kandungan dominan golongan fenolik.

b. Ekstrak methanol kulit rambutan Binjai dan Lebak bulus memiliki aktivitas sebagai antioksidan yang sebanding dengan Asam askorbat dan lebih tinggi dari pada EGCG dan BHT. 


\section{Daftar Pustaka}

[1] Anonim. 2006. Vademakum Rambutan. Jakarta : Direktorat Budidaya Tanaman Buah Departemen Pertanian.

[2] Dalimartha, S. 2007. Atlas Tumbuhan Obat Indonesia Jilid 3. Jakarta : Puspa Swara.

[3] Wijayakusuma, H. 1994. Tanaman Berkhasiat Obat Indonesia. Jakarta : Pustaka Kartini.

[4] Mishra, J., R.K. Srivasta, S.V. Shukla dan C.S. Raghav. 2007. Antioxidant in Aromatic and Medicinal Plants. Science Tech Entrepreneur.7:1-16.

[5] Thitilertdecha, N., Teerawutgulrag, A., Rakariyatman, N. 2007. Antioxidant and Antibacterial Activities of Nephelium lappaceum Extracts. LWT - Food Science and Technology. 41: 20292035

[6] Thitilertdecha, N., Teerawutgulrag, A., Jeremy D. kliburn., Rakariyatman, N. 2010. Identification of Major Phenolic Compounds from Nephelium lappaceum L. and Their Antioxidant Activities. Molecules. 15(3): 1453-1465

[7] Harborne, J. B. 1986. Metode Fitokimia. Penuntun cara Modern Menganalisis Tumbuhan. Bandung: ITB.

[8] Gordon, M. H. 2001. Measuring Antioxidant Activity. Antioxidant in Food Pratical Aplication. Woodhead Publishing Ltd. London.

[9] Molyneux, P. 2003. The Use of The Stable Free Radical Diphenylpicryhydrazyl (DPPH). For Estimating Antioxidant Activity. Songklanakarin J.Sci.Technol. 26(2): 211-219.

[10] Finney, D. J. 1952. Probit Analysis. England: Cambridge University Press. 